\title{
Folic acid clearances and basal serum folate levels in patients with thyroid disease ${ }^{1}$
}

\author{
JOHN LINDENBAUM AND FREDERICK A. KLIPSTEIN
}

\begin{abstract}
From the Department of Medicine of the College of Physicians and Surgeons, Columbia University, and the Medical Services of the Presbyterian and Francis Delafield Hospitals, New York, N.Y.
\end{abstract}

SYNOPSIS The plasma clearance of intravenously administered folic acid was abnormally rapid in all of five patients studied with untreated hyperthyroidism; in three, the basal serum $L$. casei folate $\dot{\sigma}$ level was subnormal. Four of these patients and another patient were studied at various intervals after partial or complete correction of the hyperthyroid state. Partial correction resulted in a con- 9 tinued fast clearance in one patient, a return to borderline-normal values in the second, and a normal clearance in the third. Complete euthyroidism was achieved in two patients; their clearance values $z$ had returned to borderline-normal at this time. In two patients studied after partial correction, the serum $L$. casei folate levels had become normal whereas the clearance values remained abnormally rapid.

These findings suggest that hyperthyroidism in man is associated with depletion of folate stores and subclinical deficiency of this vitamin. This is attributed to an increased demand for folic acid in the hypermetabolic state.

Decreased hepatic stores of folic acid have been observed in experimental animals made hyperthyroid by the administration of thyroid hormone (Noronha and Sreenivasan, 1959). No studies of folic acid metabolism in humans with thyrotoxicosis, however, have been reported.

The anaemia occasionally seen in thyrotoxicosis is usually associated with a normoblastic bone marrow and has been attributed to superimposed iron deficiency (Biström, 1946; Axelrod and Berman, 1951; Wallerstein and Castle, 1962). Clinical folic acid deficiency as manifested by megaloblastic anaemia has not been recognized in patients with hyperthyroidism. However, more than 85 cases of coincidental thyrotoxicosis and megaloblastic anaemia attributed to pernicious anaemia and responding to liver extract or vitamin $\mathbf{B}_{\mathbf{1 2}}$ have been reported (Boenheim, Schwimmer, and McGavack, 1945; McNichol, 1961). Since the diagnosis of pernicious anaemia was not confirmed by serum vitamin $\mathbf{B}_{12}$ assays or Schilling tests, it is possible that some of these patients may have had folic acid deficiency.

In recent years, two tests of folic acid deficiency, the plasma clearance of intravenously administered folic acid and the basal serum $L$. case $i$ folate level, have been shown to correlate well with clinically 'Supported by grants CY2332 and CRTY 5011 from the U.S. Public Health Service and ACF 25B from the American Cancer Society. Received for publication 25 February 1964. occurring folic acid deficiency states in man (Chanarin, Mollin, and Anderson, 1958; Metz, Stevens, Krawitz, and Brandt, 1961 ; Sheehy, Santini, Guerra, Angel, and Plough, 1963; Herbert, Baker, Frank, Pasher, Sobotka, and Wasserman, 1960; Cooper and Lowenstein, 1961; Waters and Mollin, 1961). Preliminary observations suggest that both tests may become abnormal in subclinical deficiency states before the development of overt haematologi- $\frac{8}{0}$ cal abnormalities (Metz, Stevens, Krawitz, and $\frac{0}{3}$ Brandt, 1961; Herbert, 1962b; Herbert, 1962c; Klipstein, 1963; Klipstein and Lindenbaum, 1963). ᄋิ The present study was undertaken to ascertain the $₹$ presence of possible subclinical folic acid deficiency 윽 in patients with thyroid disease.

\section{MATERIALS AND METHODS}

Two groups of subjects were studied: 1 Five patients with $N$ untreated thyrotoxicosis (cases 1-5), and four of these $N$ were restudied after varying degrees of improvement had $\omega$ occurred following therapy. Case 6 , the sixth patient with hyperthyroidism, was initially studied after having received three months' treatment. 2 Six patients with $\mathbb{\Phi}$ untreated hypothyroidism (cases 7-12). The clinical diagnosis in each case was confirmed by studies of $\square$ thyroid function (Table I).

Basal serum folate levels were obtained in the fasting $\stackrel{\overrightarrow{\mathbb{P}}}{\mathrm{Q}}$ state and assayed with $L$. case $i$ using a modification of $\overrightarrow{\mathbb{D}}$ the method introduced by Baker, Herbert, Frank, 
Pasher, Hutner, Wasserman, and Sobotka (1959). In this laboratory, values of $<5 \mathrm{~m} \mu \mathrm{g}$. $/ \mathrm{ml}$. are considered indicative of folic acid deficiency; values of 5 to $7 \mathrm{~m} \mu \mathrm{g} . / \mathrm{ml}$, are diagnostically indeterminate; and values of 7 to $18 \mathrm{~m} \mu \mathrm{g} . / \mathrm{ml}$. are normal. Folic acid clearance studies were performed by the technique described by Chanarin et al. (1958). An intravenous dose of $15 \mu \mathrm{g}$. folic acid per kilogram body weight was administered and serum samples, obtained three and 15 minutes after the injection, were assayed with Streptococcus faecalis. Normal subjects have been found to have serum folic acid concentrations of $75-186 \mathrm{~m} \mu \mathrm{g} . / \mathrm{ml}$. at three minutes and $21-80$ $\mathrm{m} \mu \mathrm{g} . / \mathrm{ml}$. at 15 minutes (Chanarin et al., 1958). (The organism $S$. faecalis has been found reliable for assay of administered folic acid in folic acid clearance and absorption studies.) In contrast, for determination of basal serum folate activity, assay with $L$. case $i$ is preferred, since the growth of $L$. casei is supported by 5-methyl tetrahydrofolic acid, recently shown to be the major form of folic acid activity in human serum (Herbert et al., 1962). Serum vitamin $B_{12}$ concentrations were assayed with Lactobacillus leichmannii (Spray, 1955); normal values in this laboratory range from 150 to $900 \mu \mu \mathrm{g} . / \mathrm{ml}$.

\section{RESULTS}

HYPERTHYROIDISM The results for both groups are set out in Table I. The plasma clearance of folic acid was abnormally rapid in all five of the patients studied with untreated thyrotoxicosis (Fig. 1). Basal serum $L$. casei folate levels were assayed in four of these patients and were subnormal in three; however, in no instance were the values depressed to the very low range $(<3 \mathrm{~m} \mu \mathrm{g} . / \mathrm{ml}$.) usually associated with megaloblastic anaemias due to folic acid deficiency. Case 6 was studied only after the hyperthyroid state had been partially corrected following three months of therapy. The folic acid clearance and basal serum $L$. casei folate were both normal in this patient.

Four patients (cases 1-4) were studied again after periods of two to four months' therapy had resulted in partial or complete correction of hyperthyroidism. Cases 1 and 4 had achieved euthyroidism. The plasma folic acid clearances were now borderline normal in both subjects and the basal serum $L$. casei folate concentrations, which had previously been subnormal in case 1, were now normal (Fig. 2). Cases 2 and 3 remained hyperthyroid despite four and two and a half months of treatment, respectively. The folic acid clearance remained abnormally rapid in case 2 and was borderline normal in case 3 . The previously subnormal serum $L$. casei folate level had returned to within the normal range in case 2 .

TABLE I

\begin{tabular}{|c|c|c|c|c|c|c|c|c|c|c|}
\hline \multirow{3}{*}{ Case } & \multirow{3}{*}{$\begin{array}{l}\text { Degree of } \\
\text { Symptoms } \\
(0 \text { to }++++)\end{array}$} & \multirow{3}{*}{$\begin{array}{l}\text { Pulse Rate } \\
\text { (per min.) }\end{array}$} & \multirow{3}{*}{$\begin{array}{l}\text { Weight } \\
\text { Changes (lb.) }\end{array}$} & \multirow{3}{*}{$H b(g . \%)$} & \multirow{3}{*}{$\begin{array}{l}\text { Protein- } \\
\text { bound } \\
\text { Iodine } \\
(\mu g . \%)\end{array}$} & \multirow{3}{*}{$\begin{array}{l}\text { Radioactive } \\
\text { lodine } \\
\text { Uptake } \\
(\% \text { uptake })\end{array}$} & \multirow{3}{*}{$\begin{array}{l}\text { Serum } B_{12} \\
(\mu \mu g . / m l .)\end{array}$} & \multirow{3}{*}{$\begin{array}{l}\text { Serum } \\
\text { L. casei } \\
\text { Folate } \\
(m \mu g . ! m l .)\end{array}$} & & \multirow{3}{*}{ Comments } \\
\hline & & & & & & & & & $\begin{array}{l}\text { Folic Acid Clearance } \\
\text { S. faecalis Serum } \\
\text { Levels }(m \mu g . / m l .)\end{array}$ & \\
\hline & & & & & & & & & 3 Minutes 15 Minutes & \\
\hline
\end{tabular}

\begin{tabular}{ll}
\hline \multicolumn{3}{l}{ Thyrotoxicosis } \\
la & ++++ \\
b & +++
\end{tabular}

\begin{tabular}{|c|c|c|c|c|c|c|c|c|}
\hline $\begin{array}{r}100 \\
88\end{array}$ & $\begin{array}{l}150 \\
\text { None }\end{array}$ & $\begin{array}{l}14.0 \\
14.7\end{array}$ & 19 & & $\begin{array}{l}510 \\
550\end{array}$ & $\begin{array}{l}4 \cdot 0 \\
8 \cdot 4\end{array}$ & $\begin{array}{l}39 \\
63\end{array}$ & $\begin{array}{r}3 \\
16\end{array}$ \\
\hline 80 & $\uparrow 17$ & $14 \cdot 5$ & $5 \cdot 4$ & & 800 & $9 \cdot 2$ & 78 & 18 \\
\hline $\begin{array}{l}68 \\
64 \\
60\end{array}$ & $\uparrow \begin{array}{r}18 \\
11 \\
6\end{array}$ & $\begin{array}{l}14 \cdot 5 \\
14 \cdot 7\end{array}$ & $\begin{array}{l}20 \\
8 \cdot 4\end{array}$ & 37 & $\begin{array}{l}300 \\
380 \\
455\end{array}$ & $\begin{array}{l}4 \cdot 4 \\
7 \cdot 1 \\
8 \cdot 4\end{array}$ & $\begin{array}{l}58 \\
45 \\
52\end{array}$ & $\begin{array}{l}15 \\
10 \\
11\end{array}$ \\
\hline $\begin{array}{r}110 \\
92\end{array}$ & $\begin{array}{r}20 \\
1\end{array}$ & 11.9 & $\begin{array}{l}10 \cdot 9 \\
10 \cdot 1\end{array}$ & 80 & 380 & $\begin{array}{l}8 \cdot 0 \\
9 \cdot 4\end{array}$ & $\begin{array}{l}76 \\
48\end{array}$ & $\begin{array}{l}10 \\
18\end{array}$ \\
\hline $\begin{array}{r}108 \\
92\end{array}$ & $\begin{array}{r}23 \\
8\end{array}$ & $\begin{array}{l}11 \cdot 2 \\
13 \cdot 7\end{array}$ & $\begin{array}{r}11 \cdot 3 \\
5 \cdot 5\end{array}$ & 69 & 650 & 6.0 & $\begin{array}{l}70 \\
77\end{array}$ & $\begin{array}{l}12 \\
21\end{array}$ \\
\hline $\begin{array}{r}80 \\
104\end{array}$ & $\begin{array}{l}\downarrow 10 \\
\uparrow 17\end{array}$ & $\begin{array}{l}15.9 \\
13 \cdot 2\end{array}$ & $\begin{array}{l}15 \cdot 9 \\
11 \cdot 2\end{array}$ & $\begin{array}{l}56 \\
54\end{array}$ & $\begin{array}{l}525 \\
575\end{array}$ & $\begin{array}{l}4 \cdot 0 \\
7 \cdot 0\end{array}$ & $\begin{array}{l}50 \\
70\end{array}$ & $\begin{array}{r}5 \\
30\end{array}$ \\
\hline
\end{tabular}

Untreated
After Tapazole for
2 mth., thyroidectomy
Two mth. after
thyroidectomy
Untreated
After Tapazole for 2 mth.
Four mth. after initial
studies.
Untreated
After propylthiouracil for
10 weeks
Untreated
Restudied 4 mth. after
therapeutic dose radio-
active iodine
Untreated
Following 3 mth. treat-
ment with Tapazole;
2 mth. after therapeutic
I31

\begin{tabular}{|c|c|c|c|c|c|c|c|c|c|c|c|}
\hline \multicolumn{12}{|c|}{ Myxoedema } \\
\hline 7 & $+t+t$ & 58 & $\uparrow 20$ & $12 \cdot 5$ & $1 \cdot 1$ & & 55 & $10 \cdot 3$ & 134 & 58 & \\
\hline 8 & $+t+t$ & 64 & 30 & $12 \cdot 0$ & $1 \cdot 2$ & & 450 & $8 \cdot 0$ & 200 & 57 & \\
\hline 9 & $+t+$ & 58 & $\uparrow 12$ & $12 \cdot 5$ & $2 \cdot 3$ & 13 & 450 & $14 \cdot 4$ & 50 & 35 & \\
\hline 10 & $+t+$ & 64 & $\uparrow 4$ & $12 \cdot 2$ & $2 \cdot 0$ & 5 & 410 & $8 \cdot 0$ & 46 & 43 & \\
\hline 11 & $+t+$ & 60 & $\uparrow 10$ & $10 \cdot 6$ & $1 \cdot 3$ & 9 & 725 & $12 \cdot 0$ & 80 & 20 & Haemolytic anaemia \\
\hline 12 & $+t+$ & 72 & $\uparrow 5$ & $12 \cdot 7$ & $1 \cdot 0$ & 5 & 310 & $13 \cdot 1$ & 135 & 18 & Gastrointestinal bleeding \\
\hline
\end{tabular}




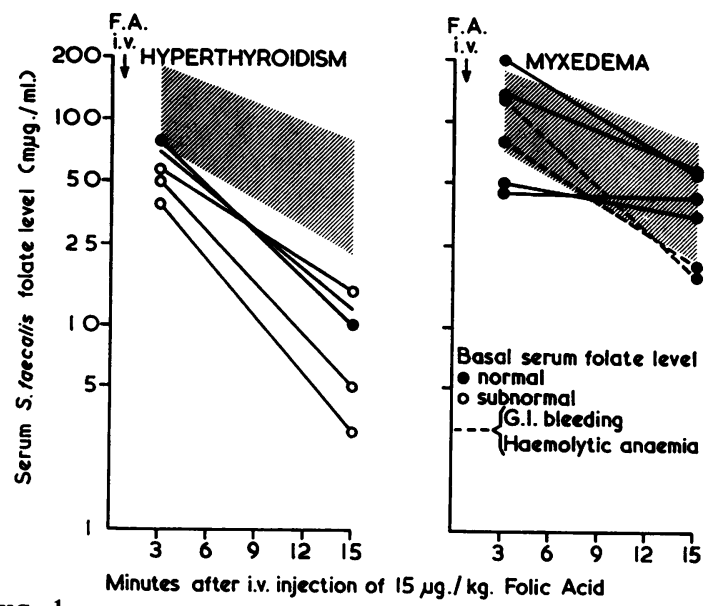

FIG. 1.

Serum vitamin $B_{12}$ concentrations were within the normal range in all patients in this group. Two patients were mildly anaemic. This was shown to be on the basis of iron deficiency in both instances and had been corrected by replacement therapy with iron in case 4 at the time of the study. None of the peripheral smears of the patients in this group showed macrocytosis or hypersegmentation of the neutrophils.

HYPOTHYROIDISM Basal serum $L$. casei folate concentrations were normal in all six patients with untreated hypothyroidism (cases 7-12). The plasma clearance of folic acid (Fig. 1) was within the normal range in four subjects (cases 7-10) and borderline normal in two patients (cases 11 and 12). Case 11 had an overt acquired haemolytic anaemia with a reticulocytosis of $6.3 \%$ at the time of study and case 12 was shown to have occult gastrointestinal bleeding.

Serum vitamin $B_{12}$ concentrations were within the normal range in all subjects in this group, with the exception of case 7 . The subnormal serum vitamin $\mathbf{B}_{12}$ level of $55 \mu \mu \mathrm{g} . / \mathrm{ml}$. in this patient was shown by absorption studies with $\mathrm{Co}^{60}$-labelled vitamin $B_{12}$ to be on the basis of latent pernicious anaemia. Macrocytosis was observed in the peripheral smear of this patient but in no other subject in this group. Case 11 was the only patient with anaemia in this group. This patient had an acquired haemolytic anaemia secondary to sulphone therapy which responded to withdrawal of the offending drug.

\section{DISCUSSION}

Abnormally rapid plasma clearances of folic acid

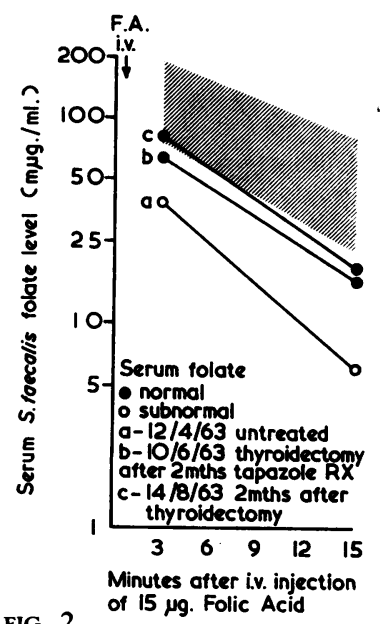

FIG. 1. Serial studies of the effect of therapy on serum folate values and folic acid clearances in a thyrotoxic patient.

FIG. 2. Folic acid clearance studies during treatment of hyperthyroidism. In both diagrams the shaded area represents the normal range for the folic acid clearance.

and subnormal concentrations of serum $L$. casei folate have been reported in states in which clinical folic acid deficiency has been recognized: megaloblastic anaemias associated with dietary deficiency of folic acid (Herbert, 1962a; Zalusky and Herbert, 1961), malabsorption (Chanarin et al., 1958; Klipstein, 1963), liver disease (Herbert, Zalusky, and Davidson, 1963; Klipstein and Lindenbaum, 1964), diphenylhydantoin therapy (Klipstein, 1964), neoplastic diseases (Chanarin and Bennett, 1962; Rama Rao, Lagerlöf, Einhorn, and Reizenstein, 1963), pregnancy (Chanarin, MacGibbon, O'Sullivan, and Mollin, 1959b; Lowenstein, Hsieh, Brunton, De Leeuw, and Cooper, 1962) and haemolytic anaemias with sencondary megaloblastic change (Chanarin et al., 1959a; Lindenbaum and Klipstein, 1963). Abnormal values for both these determinations have been observed in patients considered to have folic acid deficiency before the appearance of haematological abnormalities (Metz et al., 1961; Herbert 1962b, c; Klipstein, 1963; Klipstein and Lindenbaum, 1964; Hansen and V. Klewesahl-Palm, 1963). The available evidence suggests, therefore, that the folic acid clearance and serum $L$. case $i$ folate concentration provide sensitive indications of the adequacy of tissue stores of folic acid derivatives. The finding of abnormally rapid folic acid clearances in all five patients with untreated thyrotoxicosis and low basal serum $L$. casei folate levels in three of these patients is suggestive of depletion of folate stores with subclinical folic acid deficiency and is in accord with the laboratory observation of low hepatic stores of folic acid in hyperthyroid rats (Noronha and Sreenivasan, 1959).

Multiple vitamin deficiencies have been repeatedly observed in the experimental animal rendered 
hyperthyroid by the administration of large doses of thyroid hormone. Increased requirements for vitamin $\mathrm{A}$, thiamine, pyridoxine, pantothenic acid, vitamin $B_{12}$, and vitamin $C$, with concomitant depletion of body stores of these vitamins, have been demonstrated in a variety of laboratory animals (Drill, 1962). The most likely interpretation of the findings in the present report is that they are a reflection of an increased metabolic demand for folic acid associated with a generalized increase in coenzyme requirements associated with the hyperthyroid state. The hyperactive bone marrow typically seen in thyrotoxicosis (Axelrod and Berman, 1951) may also contribute to such an increased demand and utilization of folate. The mechanism for the subclinical folate deficiency in thyrotoxicosis may thus be analogous to that in patients with severe haemolytic anaemia. A more than four- to eight-fold increase in requirement for folic acid has recently been demonstrated in a patient with sickle cell anaemia (Lindenbaum and Klipstein, 1963).

The finding of persistently rapid folic acid clearances after partial correction of the hyperthyroid state appear to indicate a continued increased demand for folic acid even in the mildly hyperthyroid individual. The return of the serum folate levels to normal while the plasma clearances were still abnormally rapid in two patients, as well as the initial finding of a rapid plasma clearance associated with a normal serum folate level in another patient, suggests that the serum folate level is a less sensitive method than the clearance for detecting minimal depletion of folate stores. A similar experience with these two determinations has been obtained in patients with liver disease (Klipstein and Lindenbaum, 1964).

No evidence of folic acid deficiency was observed in the patients studied with myxoedema. Serum L. casei folate levels were normal in all six subjects as were folic acid clearances in the four uncomplicated cases. The borderline clearance values found in two subjects, one of whom had acquired haemolytic anaemia and the other gastrointestinal bleeding, may well be attributed to these complications since both have been associated with rapid folic acid clearances, possibly secondary to increased folate demands of the hyperactive marrow (Chanarin et al., 1959a and b; Chanarin et al., 1958; Sheehy et al., 1963; Klipstein and Lindenbaum, 1964).

While experience with megaloblastic anaemias to date has shown a high correlation between folic acid deficiency states and the tests employed in this study, caution must be exercised in the final interpretation of these tests of folic acid deficiency. It is possible that factors other than depletion of body stores of folate derivatives may contribute to abnormally rapid folic acid clearances or low serum folates. Circulatory factors may play an important role in the clearance tests. In a thyrotoxic patient with an increased cardiac output, it is conceivable that increased perfusion of the tissues during the 15 minutes after the intravenous administration of folic acid could result in increased extraction of the vitamin, leading to a rapid clearance in the absence of depletion of tissue stores. However, the finding of persistently rapid folic acid clearances even after the pulse rate had returned to normal in a partially treated patient (case 2, Table I) would argue against the contribution of circulatory factors at that time.

The possible role of the state of activity of the reticuloendothelial system also merits further consideration. Generalized hyperplasia of lymphoid tissues, and in a minority of cases, even splenomegaly, are recognized features of thyrotoxicosis (Baldridge and Peterson, 1927). The role played by the various organs of the reticuloendothelial system in the immediate extraction of folic acid from the plasma after an intravenous injection is unknown at present. Whether hyperactivity of this system could result in a rapid clearance in the absence of depletion of tissue stores is, in our present state of knowledge, merely speculative. However, in conditions such as the anaemia of infection or that associated with rheumatoid arthritis, there may be a rapid clearance of intravenously-administered iron and a depression of the serum iron level, in the absence of depletion of body iron stores (Cartwright and Wintrobe, 1952).

At the present time, the definite interpretation of the finding of abnormally rapid folic acid clearances and subnormal basal $L$. casei folate levels awaits correlation of assay of biopsy material for folate stores performed in conjunction with the plasma studies.

The authors take pleasure in acknowledging with thanks the assistance of Dr. Kenneth Sterling of the Presbyterian Hospital Thyroid Clinic in obtaining patients for study, Mrs. Florence Lefcourt for secretarial assistance, and Mrs. Patrician Weitzner for performing the microbiological assays. Requests for reprints should be directed to Dr. Klipstein.

\section{REFERENCES}

Axelrod, A. R., and Berman, L. (1951). Blood, 6, 436.

Baker, H., Herbert, V., Frank. O., Pasher, I., Hutner, S. H. Wasserman, L. R., and Sobotka, H. A., (1959). Clin. Chem., 5, 275.

Baldridge, C. W., and Peterson, F. R. (1927). J. Amer. med. Ass., $88,1701$.

Biström, O. (1946). Acta chir. scand., suppl. 114.

Boenheim, F., Schwimmer, D., and McGavack, T. H. (1945). Ann. intern. Med., 23, 869.

Cartwright, G. E., and Wintrobe, M. M. (1952). Advanc. intern. Med., $5,165$.

Chanarin, I., and Bennett, M. C. (1962). Brit. J. Haemat., 8, 95. 
Chanarin, I., Dacie, J. V., and Mollin, D. L. (1959a). Ibid., 5, 245.

_-, MacGibbon, B. M., O'Sullivan, W. J., and Mollin, D. L. (1959b). Lancet, 2, 634.

_-, Mollin, D. L., and Anderson, B. B. (1958). Brit. J. Haemat., 4, 435.

Cooper, B. A., and Lowenstein, L. (1961). Canad. med. Ass. J., 85, 987.

Drill, V. A. (1962). In The Thyroid, 2nd. ed. edited by S. C. Werner p. 607. Hoeber-Harper and Row, New York.

Hansen, H. A., and V. Klewesahl-Palm, H. V. (1963). Scand. J. clin. Lab. Invest., suppl. 69, 78.

Herbert, V. (1962a). Med. Clin. N. Amer., 46, 1365.

- (1962b). Arch. intern. Med., 110, 649.

- (1962c). Trans. Ass. Amer. Phyens, 75, 307.

- Baker, H., Frank, O., Pasher, I., Sobotka, H., and Wasserman, L. R. (1960). Blood, 15, 228.

-_, Larrabee, A. R., and Buchanan, J. M. (1962). J. clin. Invest., 41, 1134.

_- Zalusky, R., and Davidson, C. S. (1963). Ann. intern. Med., $58,977$.

Klipstein, F. A. (1963). Blood, 21, 626.
- (1964). Blood, 23, 68.

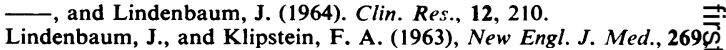
875.

Lowenstein, L., Hsieh, Y. S., Brunton, L., De Leeuw, N. K. M., and Cooper, B. A. (1962). Postgrad. Med., 31, 72. Metz, J., Stevens, K., Krawitz, S., and Brandt, V. (1961). J. clin. Path.

McNichol, G. P. (1961). Amer. J. med. Sci., 241, 336.

Noronha, J. M., and Sreenivasan, A. (1959). Biochem. J., 73, 732. Rama Rao, P. B., Lagerlöf, B. Einhorn, J., and Reizenstein, P. (1963) Lancet, 1, 1192.

Sheehy, T. W., Santini, R., Jr., Guerra, R., Angel, R., and Plough, $\vec{\odot}$ I. C. (1963). J. Lab. clin. Med. 61, 650.

Spray, G. H. (1955). Clin. Sci., 14, 661.

Wallerstein, R. O., and Castle, W. B. (1962) In The Thyroid 2nd ed edited by S. C. Werner, p. 666. Hoeber-Harper and Row New York.

Waters, A. H, and Mollin, D. L. (1961), J clin. Path, 14, 335.

Zalusky, R., and Herbert, V. (1961). New Engl. J. Med., 265, 1033

\section{The September 1964 Issue}

\section{THE SEPTEMBER 1964 ISSUE CONTAINS THE FOLLOWING PAPERS}

The changing pattern of pathology E. M. DARMADY

Pathogenesis and laboratory diagnosis of non-tuberculous urinary tract infection: A review $\mathrm{W}$. BRUMFITT and A. PERCIVAL

Bacteriological complications from the use of urethral instruments: Principles of prevention J. P. MITCHELL and $W$. A. GILLESPIE

Method for the detection of significant bacteriuria in large groups of patients D. A. LEIGH and J. D. WILLIAMS

The evaluation and modification of a technique for comparing the efficiency of antiseptics against subcutaneously deposited bacteria in mice LEONARD JEFFRIES and S. A. PRICE

Bacterial endocarditis due to an actinobacillus R. G. MITCHELL and W. A. GILLESPIE

Further observations on Mima polymorpha and Achromobacter (Bacterium) anitratum J. BRODIE and A. HENDERsON

Detection of staphylococcal antibodies by gel diffusion D. M. STANDRING

The fibrinolytic mechanism in haemostasis: A review J. L. STAFFORD

Control of anticoagulant therapy: Postal comparison between five centres

Exertional haemoglobinuria: a report on three cases with studies on the haemolytic mechanism RONALD J. L. DAVIDSON
Stromal changes in leukaemic and related bone marrow $\overrightarrow{0}$ proliferations N. G. SANERKIN

An immunochemical test for chorionic gonadotrophino T. D. ORBAN

Deoxyribonucleic acid and ribonucleic acid content of human tissues obtained at necropsy T. F. SLATER BARBARA SAWYER, and URSULA STRÄULI

Simple tests of renal function using creatinine, phenosulphonphthalein, and pitressin J. K. HEALY, K. D. G EDWARDS, and H. M. WHYTE

Measurement of $p \mathrm{H}, \mathrm{PCO}_{2}$, and standard bicarbonate on: samples of capillary blood R. S. JONES, V. R. KAMATH, and J. C. KAY

The staining of lactic dehydrogenase isoenzymes after electrophoretic separation on cellulose acetate $\mathrm{H}$.욱 BARNETT

\section{Technical methods}

A disposable counting chamber for urinary cytologyo G. R. F. HILSON

Method for the demonstration of nucleoli in lymphocytes and other blood and bone marrow cells $\mathrm{E}$. M GILLIS and A. G. BAIKIE

\section{Obituary Joan Margaret Ross}

\section{Book reviews}

Copies are still available and may be obtained from the PUBLISHING MANAGER, BRITISH MEDICAL ASSOCIATION, TAVISTOCK SQUARE, W.C.I., price 18s. 6D. 